\title{
The role of organisational performance in moderating human resource management and outstanding outcomes in open distance learning context
}

\section{Maximus Gorky Sembiring*}

Universitas Terbuka,

Pondok Cabe, Pamulang,

Tangerang Selatan, Indonesia

Email: gorky@ecampus.ut.ac.id

*Corresponding author

\section{Gayuh Rahayu}

Department of Biology,

IPB University,

Kampus Dramaga, Bogor, Indonesia

Email: gayuhrahayu@gmail.com

\section{Rizki Hersada Sembiring}

Universitas Terbuka,

Pondok Cabe, Pamulang,

Tangerang Selatan, Indonesia

Email: gurusembiring21@gmail.com

\begin{abstract}
Plausible factors interrelated in human resource management (HRM), organisational performance (OP), and outstanding outcomes (OO) in open distance learning (ODL) context laden tightly with educational technology were explored. It was aimed at exposing the moderating role of OP between HRM and OO (services, products, and systems). Qualitatively, HRM included selection and recruitment, work definition, training program, performance measurement, compensation scheme, career planning, quality assurance, and employee participation. OP was influenced by HRM and leading to OO. Quantitatively, HRM, OP, and OO were independent, moderating, and dependent variables respectively. Responses from 158 faculty were completed. Eight of 11 hypotheses assessed were validated by the analysis utilising structural equation modelling (SEM). Career planning was the most significant influence while selection and recruitment, work definition, and quality assurance were not validated. Besides, OP led to OO. Importanceperformance analysis (IPA) and customer-satisfaction index (CSI) discovered 18 attributes as the pillars of HRM and OP.
\end{abstract}

Keywords: ODL; open distance learning; HRM; human resource management; organisational performance; IPA; importance-performance analysis; CSI; customer-satisfaction index; SEM; structural equation modelling.

Reference to this paper should be made as follows: Sembiring, M.G., Rahayu, G. and Sembiring, R.H. (2021) 'The role of organisational performance in moderating human resource management and outstanding 
outcomes in open distance learning context', Int. J. Mobile Learning and Organisation, Vol. 15, No. 2, pp.212-231.

Biographical notes: Maximus Gorky Sembiring is a Professor at Universitas Terbuka. His research mainly focuses on the student support system and organisational performance in an open distance learning environment.

Gayuh Rahayu is an Associate Professor in the Department of Biology, IPB University, Bogor, Indonesia. Most of her researches mainly focus on student academic performance.

Rizki Hersada Sembiring is a professional independent translator. He graduated from Universitas Terbuka and IPB University, Bogor, Indonesia.

This paper is a revised and expanded version of a paper entitled 'Sanctioning the Role of Organizational Performance in Moderating Human Resource Management and Outstanding Outcomes in ODL Setting' presented at the '33rd Annual Conference of the Asian Association of Open Universities', Virtual University, Lahore, Pakistan, 14-16 October 2019.

\section{Introduction}

Human resources management (HRM) was considered as the origin of organisational performance (OP) in the era of modern management (Becker and Gerhart, 1996). To a certain extent, it was initially identified that selection and recruitment, work definition, training program, performance measurement, compensation scheme, career planning, and employee participation were counted as some of the factors in HRM discourse. These configurations were highlighted by Harsasi (2018) in the Universitas Terbuka context. Universitas Terbuka is a State University, the only institution operating a single mode of open distance learning (ODL) in Indonesia and tightly laden with the use of educational technology (Sembiring, 2018c).

In addition, the OP was leading to outstanding outcomes (OO) as had been summarised by Patro (2013). OO, in this inquiry, related to service excellence, quality products, and reliable systems. Moreover, they were further enumerated in educational sectors by Akhtar et al. (2011). Several factors leading to an OP with respect to OO perceived from HRM outlooks had also been underlined by Schuler and Jackson (2014). Those endeavours were significant for ODL stakeholders. Some universities still strived to secure service excellence, quality products, and reliable systems. These were totally organised and supported by information communication technology (ICT). This situation is also relevant to the Universitas Terbuka context, especially in the adoption of educational technology attributes (Sembiring, 2018a; Sembiring, 2018c). Many universities were still unsuccessfully sustaining them as HRM with respect to the existence of OP was still under the required standard (Sembiring, 2015; Sembiring and Rahayu, 2019). Why is it so? Since in an ODL setting the specificity of the pedagogical work in the learning process is highly related to the importance of technological resources (Haddad, et al., 2014).

Besides, there was still a minor question left on how OP within ODL institutions in assuring $\mathrm{OO}$ (service excellence, quality products, and reliable systems). Several basic uncertainties, for instance, on: (1) The quality of services delivered by the University so 
that students may achieve their academic target. (2) The quality of products provided by the University and utilised by students so that they are comparable to what was offered by face-to-face universities. (3) The reliability of the system established related to assuring zero defect on registration, logistical, and examination support systems. It is also relevant to have wary whether the ultimate of OP based on HRM with respect to OO in the ODL setting will guarantee the high-quality products of the University. All these interests were relevant to the Universitas Terbuka context (Sembiring, 2018a; Sembiring, 2018b).

After comprehensively considering those critical issues, this study was aimed at investigating significant factors (variables, dimensions, and/or attributes) as the origin of HRM towards service excellence, quality products, and reliable systems (OO) moderated by OP. In detail, this study explores: (1) What are factors underpinning OP. (2) How will OP influence OO. (3) How are interrelations amongst all factors (HRM, OP, and OO) engaged and in what routines they interrelated one another. (4) How are the details between HRM and OP with respect to OO in the Universitas Terbuka tradition identified by the faculty. This rationale was the uniqueness of this inquiry compared to the other setting presumed it is conducted in conventional universities.

\section{Literature review and the context}

To start with, HRM practices in this inquiry, to a certain extent, were defined as the activities intended to enhance the performance of an organisation, especially staff ability to achieve high-quality outcomes. Moreover, it was initially recognised there were seven fundamentals of HRM related to OP. They were previously amalgamated as selection and recruitment, work definition, training program, performance measurement, compensation scheme, career planning, and employee participation (Harsasi, 2018). HRM and OP attracted many scholars in a wide variety of disciplines (Torabia and El-Denb, 2017). Earlier findings by Kanyemba et al. (2015), provided constructive support to use this groundwork as it also fits in the higher education context (Shefali and Srivastava, 2017); including in Universitas Terbuka. The origin of the study was on HRM and OP integrated with other prominent constructs with respect to delivering service excellence, generating quality products, and establishing reliable systems and they were referred to as the socalled OO (Sembiring, 2017). An equivalent configuration was acknowledged as they have identified that OP led to increased service excellence. Besides, OP has direct effects on quality products and reliable systems. It is believed that more organisations expected to gain more reliable systems (Imran et al., 2012).

Referring to the previous elaboration, OP in this study behold from HRM outlooks with a slightly different set of dimensions as introduced by Harsasi (2018) and also with quite different consequences as well. In this study, knowledge on quality assurance, as an essential element of HRM, was included as emphasised by Sayfried and Pohlenz (2018). Having completed a comprehensive qualitative method through a series of activities (literature review and focus group discussion), the study comes to propositioning the following configuration as the conceptual framework of the study (Figure 1).

These elaborated key elements (Figure 1) are related to the vision of Universitas Terbuka to be a world quality university (Universitas Terbuka, 2017). World quality is referred to as the corollary of OP as a total system applied by the University. It is achieved by referring to HRM with respect to assuring effective OP. Besides, it had 
direct effects on $\mathrm{OO}$ (service excellence, quality products, and reliable systems) through the Universitas Terbuka tradition. Therefore, OP is conceptually defined as the ultimate goal of the HRM system leading to OO empirically witnessed and experienced by the academic staff of the University.

Figure 1 The conceptual framework of the study

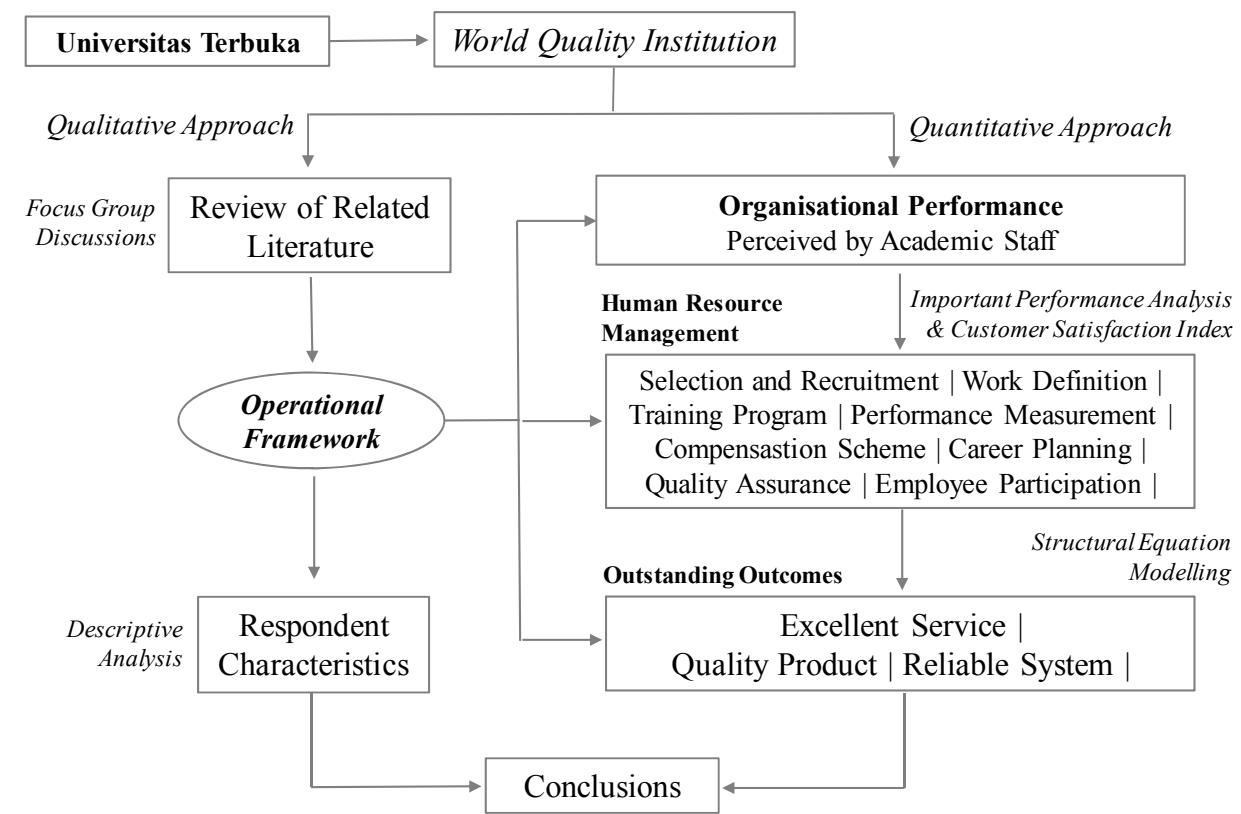

After completing the conceptual framework and definition, we proceed to the operational stage, as suggested by mixed-methods, i.e., exploratory design (Creswell and Clark, 2011). It was designed that the next operational framework was the elaboration of the conceptual framework (Figure 1). In the operational stage, there will be an elaboration of factors engaged to first develop the operational definitions. These sets of factors, through literature review and focus group discussion activities, the study is systematically originating the following set of variables and then followed by their related dimensions/attributes, as exhibited in Table 1.

Referring to Table 1, we are now in a position to establish the operational definitions of related variables specifically adjusted for this study. Operationally, selection and recruitment $\left(\mathrm{X}_{1}\right)$ were defined as the first dimension of HRM in assuring the system is transparent, fair, and based on knowledge, skill, and attitude in employing and empowering the staff. Work definition $\left(\mathrm{X}_{2}\right)$ was defined as the second dimension of HRM in confirming that it was clearly defined, explicable, and applicable to everyone. Training program $\left(\mathrm{X}_{3}\right)$ was defined as the third dimension of HRM in securing that it is based on real needs, official, and scheduled regularly. Performance measurement $\left(\mathrm{X}_{4}\right)$ was defined as the fourth dimension of HRM in guaranteeing that it is under direct supervision, structured, and target-oriented. 
Table 1 Variables and dimensions of the study

\begin{tabular}{|c|c|c|c|c|c|}
\hline No. & Variables & Dimensions & No. & Variables & Dimensions \\
\hline 1 & $\begin{array}{l}\mathbf{X}_{1} \\
\text { Selection and } \\
\text { Recruitment }\end{array}$ & $\begin{array}{l}\mathrm{X}_{11}: \text { Transparent } \\
\mathrm{X}_{12}: \text { Fair } \\
\mathrm{X}_{13}: \text { Based on } \\
\text { Knowledge skill, and } \\
\text { attitude }\end{array}$ & 2 & $\begin{array}{l}\mathbf{X}_{2} \\
\text { Work } \\
\text { Definition }\end{array}$ & $\begin{array}{l}\mathrm{X}_{21}: \text { Clearly defined } \\
\mathrm{X}_{22}: \text { Explicable } \\
\mathrm{X}_{23}: \text { Practicable }\end{array}$ \\
\hline 3 & $\begin{array}{l}\mathbf{X}_{\mathbf{3}} \\
\text { Training Programs }\end{array}$ & $\begin{array}{l}\mathrm{X}_{31}: \text { Based on needs } \\
\mathrm{X}_{32}: \text { Official } \\
\mathrm{X}_{33}: \text { Scheduled }\end{array}$ & 4 & $\begin{array}{l}\mathbf{X}_{4} \\
\text { Performance } \\
\text { Measurement }\end{array}$ & $\begin{array}{l}\mathrm{X}_{41}: \text { Direct } \\
\text { supervision } \\
\mathrm{X}_{42}: \text { Structured } \\
\mathrm{X}_{43}: \text { Target oriented }\end{array}$ \\
\hline 5 & $\begin{array}{l}\mathbf{X}_{\mathbf{5}} \\
\text { Compensation } \\
\text { Scheme }\end{array}$ & $\begin{array}{l}\mathrm{X}_{51}: \text { Performance- } \\
\text { based } \\
\mathrm{X}_{52}: \text { Attractive } \\
\mathrm{X}_{53}: \text { Tangible- } \\
\text { Intangible }\end{array}$ & 6 & $\begin{array}{l}\mathbf{X}_{6} \\
\text { Career } \\
\text { Planning }\end{array}$ & $\begin{array}{l}\mathrm{X}_{61} \text { : Observable } \\
\text { ladder } \\
\mathrm{X}_{62} \text { : Good for } \\
\text { everyone } \\
\mathrm{X}_{63} \text { : Guaranteeing }\end{array}$ \\
\hline 7 & $\begin{array}{l}\mathbf{X}_{7} \\
\text { Quality Assurance }\end{array}$ & $\begin{array}{l}\mathrm{X}_{71}: \text { Applicable } \\
\mathrm{X}_{72}: \text { Dependable } \\
\mathrm{X}_{73}: \text { Valuable }\end{array}$ & 8 & $\begin{array}{l}\mathbf{X}_{\mathbf{8}} \\
\text { Employee } \\
\text { Participation }\end{array}$ & $\begin{array}{l}\mathrm{X}_{81}: \text { Developing a } \\
\text { vision } \\
\mathrm{X}_{82}: \text { Making a } \\
\text { decision } \\
\mathrm{X}_{83}: \text { Appointing } \\
\text { official }\end{array}$ \\
\hline 9 & $\begin{array}{l}Y_{1} \\
\text { Organisational } \\
\text { Performance }\end{array}$ & $\begin{array}{l}\mathrm{Y}_{11}: \text { Academically } \\
\text { certifiable } \\
\mathrm{Y}_{12}: \text { Nationally } \\
\text { reputable } \\
\mathrm{Y}_{13}: \text { Globally } \\
\text { respectable }\end{array}$ & 10 & $\begin{array}{l}\mathbf{Y}_{2} \\
\text { Excellent Service }\end{array}$ & $\begin{array}{l}\mathrm{Y}_{21}: \text { Academic } \\
\text { service } \\
\mathrm{Y}_{22}: \text { Operational } \\
\text { service } \\
\mathrm{Y}_{23}: \text { Administrative } \\
\text { service }\end{array}$ \\
\hline 11 & $\begin{array}{l}\mathbf{Y}_{\mathbf{3}} \\
\text { Quality } \\
\text { Product }\end{array}$ & $\begin{array}{l}\mathrm{Y}_{31}: \text { Graduates } \\
\mathrm{Y}_{32}: \text { Publication } \\
\mathrm{Y}_{33}: \text { Social } \\
\text { responsibility }\end{array}$ & 12 & $\begin{array}{l}\mathbf{Y}_{\mathbf{4}} \\
\text { Reliable } \\
\text { System }\end{array}$ & $\begin{array}{l}\mathrm{Y}_{41} \text { : ICT set-up } \\
\mathrm{Y}_{42}: \text { The feedback } \\
\text { loop } \\
\mathrm{Y}_{43} \text { : Referral scheme }\end{array}$ \\
\hline
\end{tabular}

Equally, the compensation scheme $\left(\mathrm{X}_{5}\right)$ was defined as the fifth dimension of HRM in reassuring that it is performance-based, attractive enough, and considering the tangible and intangible reward options. Career planning $\left(\mathrm{X}_{6}\right)$ was defined as the sixth dimension of HRM in inspiring staff to have an observable ladder, fair for everybody, and also secured. Quality assurance knowledge $\left(\mathrm{X}_{7}\right)$ was defined as the seventh dimension of HRM in reinforcing that it is applicable, dependable, and valuable for staff and the University. Employee participation $\left(\mathrm{X}_{8}\right)$ was defined as the eighth dimension of HRM in strengthening the role of staff in developing the institutional vision, making a decision, and appointing personnel for the righteousness of the University management in the future.

OP $\left(\mathrm{Y}_{1}\right)$ was operationally defined as a condition where the ultimate goals of the HRM system generate the University's quality and brand image in academic communities so it will be academically certifiable, nationally reputable, and globally 
respectable. Moreover, the OO were defined as the congregation of service excellence, quality products, and reliable systems effusively. Service excellent $\left(\mathrm{Y}_{2}\right)$ as an element of $\mathrm{OO}$ was defined as the ultimate goal of the inclusive practice of service in academic, operational, and administrative properties. Quality product $\left(\mathrm{Y}_{3}\right)$ was defined as the function of OP to: produce quality graduates, disseminate trustworthy publications, and present highly social responsibility programs. Reliable system $\left(\mathrm{Y}_{4}\right)$ was defined as the function of OP to: build established IT set-up, provide a strong feedback loop, and deliver a comprehensive referral scheme. Having defined those related factors, again, they are much easier to follow as formerly exhibited in Table 1.

This structure (Table 1) will be employed to establish the operational framework and quantitatively scrutinised afterward. The operational framework is consolidated by reflecting the grand design of the study (Figure 1) and it is a manifestation of factors involved as illustrated in Table 1. The operational framework will come with the hypotheses of the study and they will be examined under a quantitative approach with the help of the SEM technique.

\section{Research design and the operational framework}

This research used mixed methods, namely exploratory design. It means that the qualitative approach implemented first and then followed by quantitative series (Creswell and Clark, 2011). The elaboration of the conceptual and operational definitions previously defined are necessities as a continuance of the conceptual framework toward establishing the operational framework. In the qualitative stage, five selected experts were asked a set of questions related to the main determinants of OP. The first three experts were from the top management of the University. The second two experts were senior lectures with adequate experience in several task forces within the University level; they are from the Department of Management. The first set of the question was regarding plausible factors with respect to OP as a moderating variable. The second set of the question was regarding the dimensions and other related attributes of OP, including the related dimension of HRM as the independent variables. The third set of the question was related to the impact of OP in terms of acquiring OO. After accumulating results from this stage, the study comes to the proposition on the main factors of OP leading to proceed excellent service, quality products, and reliable systems.

Having amalgamated the results from the qualitative series, we then come to proposition the operational framework of the study as displayed in Figure 2.

This operational framework (Figure 2) will be utilised as a basis to statistically infer the quantitative results afterward. Besides, it is applied as a basis to determine research design before confirming the analysis, primarily establishing the set of hypotheses. This should be completed first prior to deducing the conclusion under the quantitative procedure. It is in this stage to see how importance-performance analysis (IPA), customer-satisfaction index (CSI), and structural-equation modelling (SEM) operated concurrently as used by Sembiring (2018b) and Sembiring and Rahayu (2019).

To get those stated results completed, the next stage is to develop an instrument in the form of a questionnaire, as part of a quantitative method. Instruments for the quantitative approach consisted of 64 statements in total and they are Likert Scale, ranging from 1-5 (strongly dissatisfaction/unimportant up to strongly agree/important). They are developed with respect to satisfaction level and their importance degree. Besides, 10 items are 
proposed as additional statements to validate the independent variables (HRM) related to the dependent variables (OO) and moderated by moderating variable (OP). The questionnaire is explored considering factors engaged as suggested by Shahzavar and Tan (2011).

Figure 2 The operational framework of the study

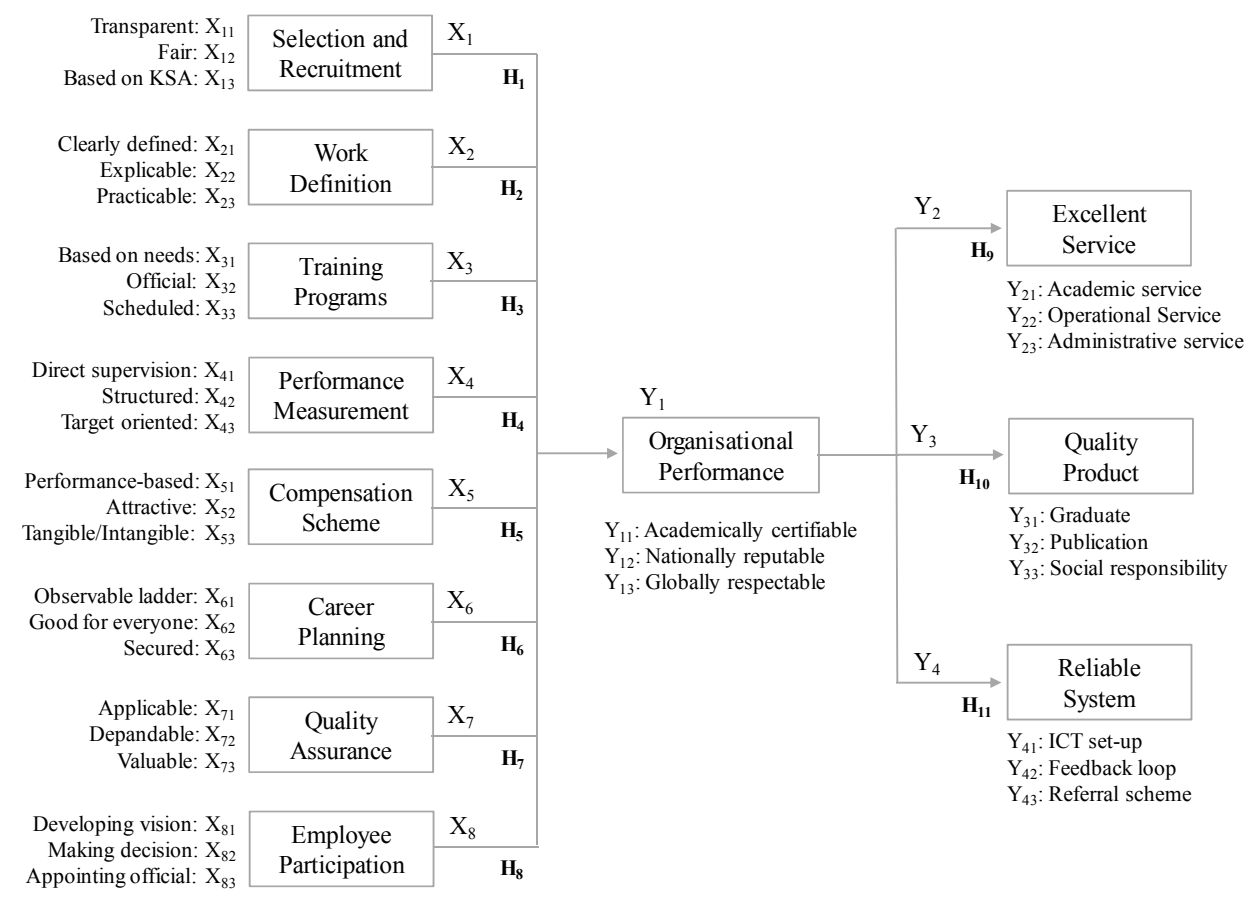

In Table 1 and Figure 2, the factors symbolised by $\mathrm{X}_{1}-\mathrm{X}_{8}, \mathrm{Y}_{1}$, and $\mathrm{Y}_{2}-\mathrm{Y}_{4}$ are independent, moderating, and dependent variables respectively. Each variable has three dimensions and each dimension is accordingly measured by a single statement. Statements in $\mathrm{X}_{1}-\mathrm{X}_{8}$, and $\mathrm{Y}_{1}$ will be answered two times concurrently by respondents. The first answer to the statements is measuring the satisfaction level. The second answer to the same statements is measuring the importance degree. $Y_{1}$ was influenced by $X_{1}-X_{8}$ and $Y_{2}-Y_{4}$ are influenced by $Y_{1}$. Statements included in $Y_{2}-Y_{4}$ are answered once with a single statement in accordance with related dimensions. So, total statements are $\left[(27 \times 2)+(1 \times 9)+1^{*}\right]=64$. Total attributes: $\left[\left(X_{1}-X_{8}\right.\right.$ and $\left.Y_{1}\right)$ with three attributes for each dimension $]=27$. The last one statement $[*]$ is on the overall perception of respondents of existing $\mathrm{OP}$ in the University based on their true and real experiences [Note: The complete questionnaire is incorporated in Appendix A].

Purposive sampling was chosen to select resource persons (five experts) for qualitative purposes. Simple random sampling was used to determine respondents for quantitative purposes (Cochran, 1977). A survey was started to accumulate data from respondents (Fowler, 2014). The population of the study is all 631 academic staff of Universitas Terbuka. The IPA-CSI was applied to simultaneously measure the level of staff satisfaction along with their importance degree related to OP and HRM (following 
Wong et al., 2011). SEM is then applied to detect relations power amongst all variables and dimensions engaged (Marks, et al., 2005; Hair et al., 2009).

This inquiry finally established and scrutinised eleven hypotheses $\left(\mathrm{H}_{1}-\mathrm{H}_{11}\right.$, Figure 2). They are: OP $\left(\mathrm{Y}_{1}\right)$ is influenced by: selection and recruitment $\left(\mathrm{H}_{1}\right)$, work definition $\left(\mathrm{H}_{2}\right)$, training program $\left(\mathrm{H}_{3}\right)$, performance measurement $\left(\mathrm{H}_{4}\right)$, compensation scheme $\left(\mathrm{H}_{5}\right)$, career planning $\left(\mathrm{H}_{6}\right)$, quality assurance knowledge $\left(\mathrm{H}_{7}\right)$, and employee participation $\left(\mathrm{H}_{8}\right)$. Besides, service excellent $\left(\mathrm{H}_{9}\right)$, quality product $\left(\mathrm{H}_{10}\right)$, and reliable system $\left(\mathrm{H}_{11}\right)$ are influenced by $\mathrm{OP}\left(\mathrm{Y}_{1}\right)$.

These hypotheses will be scrutinised with the help of the SEM technique to validate the power of the relations amongst variables and dimensions engaged. The validation is aimed at analysing the significance level of the relations. Having validated the significance level, it is then applied to scrutinise their relations power.

\section{Results and discussions}

Prior to conferring the results, it is good to note the summary of respondents' characteristics (Table 2). This will induce our perception on how to more properly interpret the outcomes.

Table 2 Respondents characteristics

\begin{tabular}{|c|c|c|c|c|c|}
\hline Respondents: 158 (631) & $\%$ & $\%$ & $\%$ & $\%$ & $\%$ \\
\hline \multirow{2}{*}{ Faculty of Echelon } & \multicolumn{3}{|c|}{ Education $=36$ Social $=22$ Economics $=19$} & \multicolumn{2}{|l|}{ Sciences $=23$} \\
\hline & One $=0$ & Two $=2$ & Three $=2$ & Four $=3$ & Non-Ech $=93$ \\
\hline Work Experience year & $1-5=2$ & $6-10=20$ & $11-15=28$ & $16-20=39$ & $\geq 21=11$ \\
\hline Age year & $\leq 30=2$ & $31-40=13$ & $41-50=28$ & $51-60=45$ & $\geq 61=12$ \\
\hline Academic Position & Professor $=0$ & Senior $=18$ & Lecturer $=78$ & Assistant $=1$ & Candidate $=3$ \\
\hline Background & $\mathrm{S} 3=10$ & $\mathrm{~S} 2=90$ & Office & Central $=49$ & Regional $=51$ \\
\hline
\end{tabular}

The population of the study was the faculty of Universitas Terbuka. We provided and distributed 631 questionnaires in total and 158 of them were finally returned and processed. One-third of the respondents are from the Faculty of Education. Respondents can be categorised as experienced staff within the University with five years or more of work experience. Half of them are working in the central office and the rests are domiciled in other 40 regional offices scattered throughout Indonesia. Most of them have been involved in various levels of management (including in the task forces) in Universitas Terbuka. This implies that insights accumulated were considered to be adequate and representative.

Hypothesis analysis. The statistical analysis reveals that three out of the 11 hypotheses established and assessed are invalidated by the analysis (Figure 3). 
Figure 3 Hypotheses analysis and the loading factors

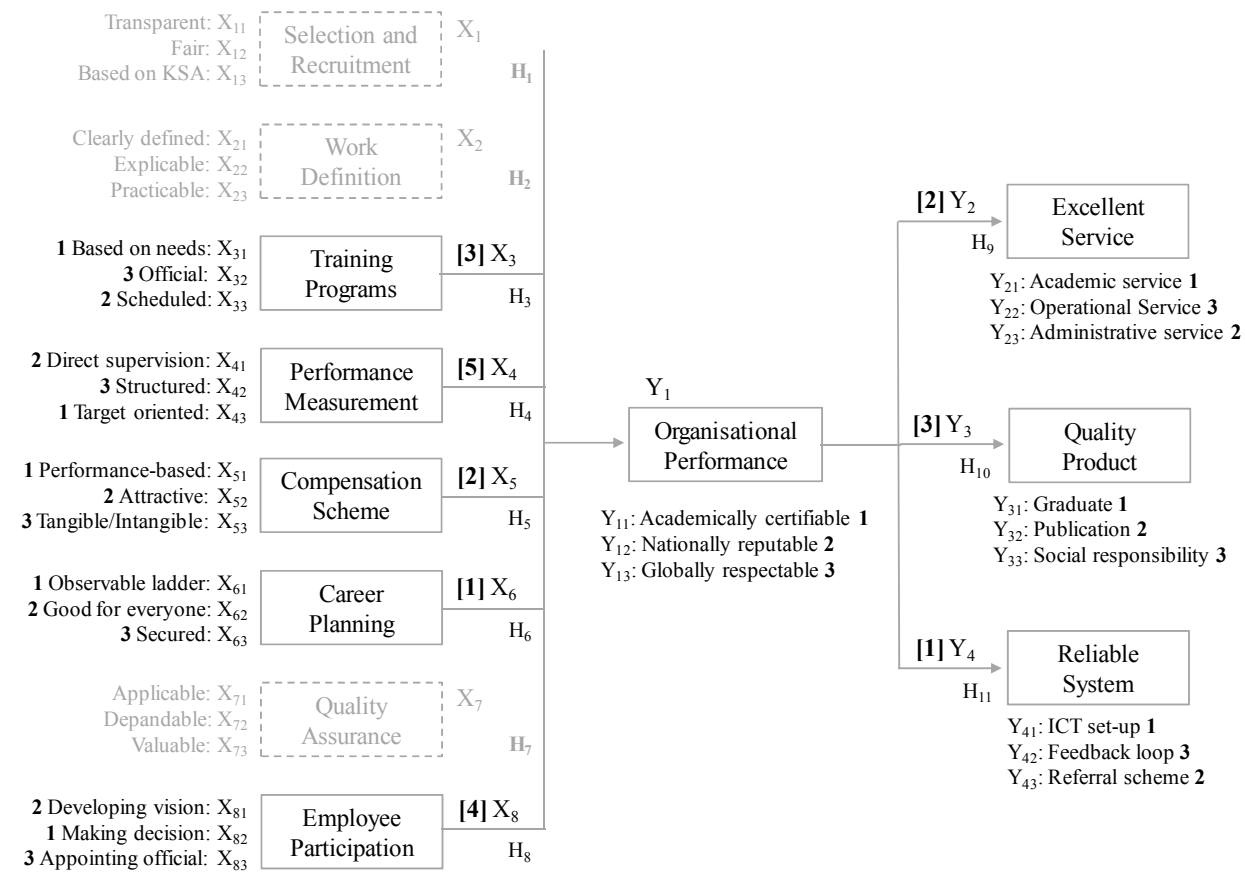

The three hypotheses are: selection and recruitment $\left(\mathrm{H}_{1}\right)$, working definition $\left(\mathrm{H}_{2}\right)$, and quality assurance knowledge $\left(\mathrm{H}_{7}\right)$ with respect to OP, since the $\mathrm{p}_{\text {-value }} \leq 1.96$, for $\alpha=5 \%$. On the contrary, the other eight hypotheses are authenticated by the analysis, since the $p_{\text {-value }} \geq 1.96$, for $\alpha=5 \%$. The eight validated hypotheses are: training program $\left(\mathrm{H}_{3}\right)$, performance measurement $\left(\mathrm{H}_{4}\right)$, compensation scheme $\left(\mathrm{H}_{5}\right)$, career planning $\left(\mathrm{H}_{6}\right)$, and employee participation $\left(\mathrm{H}_{8}\right)$ with respect to OP; and so is OP to service excellence $\left(\mathrm{H}_{9}\right)$, quality products $\left(\mathrm{H}_{10}\right)$, and reliable systems $\left(\mathrm{H}_{11}\right)$.

Prior to elucidating the loading factors analysis and its result, let us reveal the satisfaction level of HRM and OP and the degree of their importance engendered by the IPA-CSI Chart. The analysis stimulates attributes related to the relevant quadrants to distinguish their behaviour. Graphically, the IPA-CSI Chart has four quadrants (Q). $Q_{1}$ indicates that the satisfaction level of OP and HRM attributes are at a low level while the degree of their importance is high. $\mathrm{Q}_{2}$ indicates that both the satisfaction level of OP and HRM attributes and the degree of their importance are being placed at a high level. $\mathrm{Q}_{3}$ indicates that the satisfaction level of OP and HRM attributes and the degree of their importance are both at a low level. $\mathrm{Q}_{4}$ indicates that OP and HRM attributes are in the low level of importance but high in satisfaction; following Deng and Pierskalla (2018). The IPA-CSI Chart of this study is shown in Figure 4. 
Figure 4 The IPA-CSI chart of OP and HRM

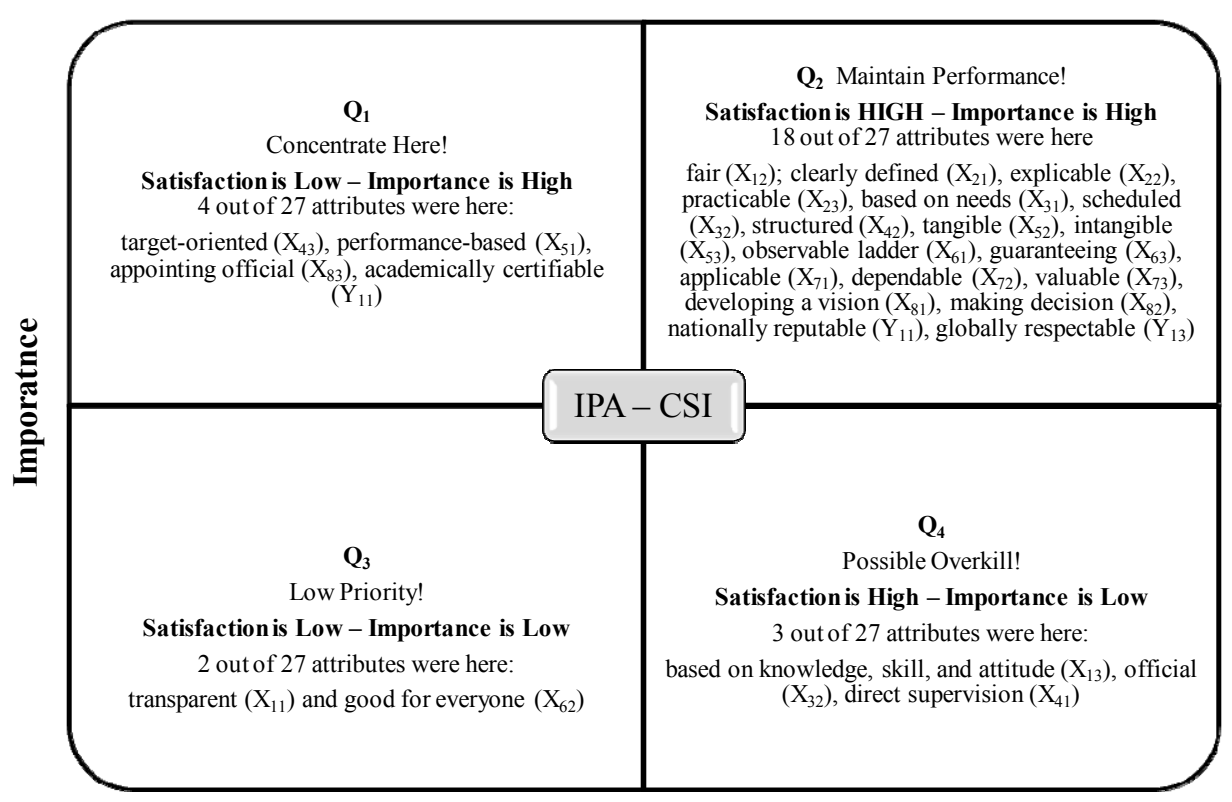

Satisfaction

$\mathrm{Q}_{1}$ [Concentrate Here: satisfaction is low, importance is high!]. Four out of 27 attributes fall into this quadrant (Figure 4). They are: target-oriented $\left(\mathrm{X}_{43}\right)$, performance-based $\left(\mathrm{X}_{51}\right)$, appointing official $\left(\mathrm{X}_{83}\right)$, and academically certifiable $\left(\mathrm{Y}_{11}\right)$. This implies that the University must notice these four attributes seriously. They are important but low in satisfaction. It means that most faculty have already been aware of the ultimate OP progress related to having service excellence, quality products, and reliable systems. OO can only be achieved if and only if these four attributes are in the $Q_{2}$ instead of in $Q_{1}$.

$\mathrm{Q}_{2}$ [Maintain Performance: satisfaction is high, importance is high!]. 18 out of 27 attributes fall into this quadrant (Figure 4). They are: fair $\left(\mathrm{X}_{12}\right)$; clearly defined $\left(\mathrm{X}_{21}\right)$, explicable $\left(\mathrm{X}_{22}\right)$, and practicable $\left(\mathrm{X}_{23}\right)$; based on needs $\left(\mathrm{X}_{31}\right)$ and scheduled $\left(\mathrm{X}_{32}\right)$; structured $\left(\mathrm{X}_{42}\right)$; tangible $\left(\mathrm{X}_{52}\right)$ and intangible $\left(\mathrm{X}_{53}\right)$; observable ladder $\left(\mathrm{X}_{61}\right)$ and guaranteeing $\left(\mathrm{X}_{63}\right)$; applicable $\left(\mathrm{X}_{71}\right)$, dependable $\left(\mathrm{X}_{72}\right)$, and valuable $\left(\mathrm{X}_{73}\right)$; developing a vision $\left(\mathrm{X}_{81}\right)$ and making a decision $\left(\mathrm{X}_{82}\right)$; nationally reputable $\left(\mathrm{Y}_{11}\right)$ and globally respectable $\left(\mathrm{Y}_{13}\right)$. The University must take care of these 18 attributes purposefully as they are the best elements of HRM and OP of the real existing condition. Attributes fall in this quadrant are the strengths and pillars of promoting excellent service, quality products, and reliable systems in Universitas Terbuka ambiance in terms of assuring OO. Besides, these 18 attributes should become the pride of the University as a basis of developing and maintaining better outcomes in the future. Providentially, most faculty members have been aware of these attributes as an assurance to provide better outcomes as expected by all staff.

$\mathrm{Q}_{3}$ [Low Priority: satisfaction is low, importance is low!]. Two attributes fall into this quadrant (Figure 4). They are: transparent $\left(\mathrm{X}_{11}\right)$ and good for everyone $\left(\mathrm{X}_{62}\right)$. The university should classify these two attributes as the next focus after concentrating to 
maintain critical points in $\mathrm{Q}_{2}$. Any attribute falling into this quadrant is not critical and poses no threat. The University may redirect resources to these attributes and shift them into $\mathrm{Q}_{2}$.

$\mathrm{Q}_{4}$ [Possible Over Kill: satisfaction is high, importance is low!]. Three attributes fall into this quadrant (Figure 4). They are: based on knowledge, skill, and attitude $\left(\mathrm{X}_{13}\right)$, official $\left(\mathrm{X}_{32}\right)$, and direct supervision $\left(\mathrm{X}_{41}\right)$. Attention to attributes in this quadrant can be even less focused. The university can save cost and energy by redirecting them to take up the vital spots by simultaneously anticipating no attributes will fall all over again into $\mathrm{Q}_{1}$ and keep maintaining the existing fundamental spots in $\mathrm{Q}_{2}$.

Having positioned attributes in accordance with the IPA-CSI chart, we then relate the loading factors to observe the power of relations of each variable under the SEM technique to work out the results (Marks et al., 20015; Hair et al., 2009). From Figure 3, at least there are five fundamental consequences need to be elaborated further.

The first effect was related to the variables/dimensions that directly influenced OP (Figure 3 ). They are: career planning $\left(\mathrm{X}_{6}\right)$ and then orderly followed by compensation scheme $\left(\mathrm{X}_{5}\right)$, training program $\left(\mathrm{X}_{3}\right)$, employee participation $\left(\mathrm{X}_{8}\right)$, and performance measurement $\left(\mathrm{X}_{4}\right)$. On the contrary, OP is statistically not influenced by selection and recruitment $\left(\mathrm{X}_{1}\right)$, work definition $\left(\mathrm{X}_{2}\right)$, and quality assurance knowledge $\left(\mathrm{X}_{7}\right)$.

It needs further explanation on how these three factors, as independent variables, are excluded by the quantitative analysis. This result evidently goes back to the classic use of two different methods to produce expected convergent findings. That is to get essentially the same results through sources that have different strengths and weaknesses. How? By asking basic questions concerning the main motives. Are they related to: a theoretical concern, a methodical question, and/or a technical problem while doing triangulation processes in a qualitative stage? Most of the work on the discrepancy, however, falls under the heading of divergence in triangulation. In the triangulation stage, it needs to conduct two independent studies on the same research questions. All the same, the classic goal is to have them agree (convergence) and it becomes different if they disagree (divergence).

The second effect is concerning the order of attributes in career planning $\left(\mathrm{X}_{6}\right)$; refer back to Figure 3 . They are: observable ladder $\left(\mathrm{X}_{61}\right)$, good for everyone $\left(\mathrm{X}_{62}\right)$, and secured $\left(\mathrm{X}_{63}\right)$; the same in order as compared to the initial framework. The order of attributes in compensation scheme $\left(\mathrm{X}_{5}\right)$ is: performance-based $\left(\mathrm{X}_{51}\right)$, attractive $\left(\mathrm{X}_{52}\right)$, and tangibletangible $\left(\mathrm{X}_{53}\right)$; the same in order as compared to the initial framework. The order of attributes in the training program $\left(\mathrm{X}_{3}\right)$ is: based on needs $\left(\mathrm{X}_{31}\right)$, official $\left(\mathrm{X}_{33}\right)$, and scheduled $\left(\mathrm{X}_{32}\right)$; slightly different in order as compared to the initial framework. The order of attributes in employee participation $\left(\mathrm{X}_{8}\right)$ is: making a decision $\left(\mathrm{X}_{82}\right)$, developing a vision $\left(\mathrm{X}_{81}\right)$, and appointing official $\left(\mathrm{X}_{83}\right)$; also slightly different in order as compared to the initial framework. The order of attributes in performance measurement $\left(\mathrm{X}_{4}\right)$ is: target-oriented $\left(\mathrm{X}_{43}\right)$, direct supervision $\left(\mathrm{X}_{41}\right)$, and structured $\left(\mathrm{X}_{42}\right)$; slightly different in order as compared to the initial framework.

The same issue as the first effect also happens in this regard. Three out of the six validated hypotheses have a different order in their dimensions. It clearly needs supplementary details about why the order in these three dimensions is different from the initial tested operational framework. What would be the plausible drives. Are they related to: the development of the questionnaire, data processing, and/or size of samples? Both quantitative and qualitative results need to be further discussed in light of the underlying philosophy of science that it is promoting in this study. 
The third is related to the power of relations of the moderating variable and dependent variables. OP has significant effects on the reliable systems $\left(\mathrm{Y}_{4}\right)$ and then orderly followed by service excellence $\left(\mathrm{Y}_{2}\right)$ and quality products $\left(\mathrm{Y}_{3}\right)$. Unequally, in the initial framework, the order is service excellence $\left(\mathrm{Y}_{2}\right)$, quality product $\left(\mathrm{Y}_{3}\right)$, and reliable system $\left(\mathrm{Y}_{4}\right)$. Similar to the previous doubt, it also occurs in this spot. The order of both variables and their dimensions are quite different as compared to the initial operational framework (Figure 3).

It visibly needs additional evidence on why this symptom appeared. Again, what would be the probable reasons. Are they related to: a theoretical, methodical, and/or technical uncertainties? Good to note that the mixed methods intend should complement one another. But, quantitative and qualitative approaches do not really assess the same. Therefore, their findings cannot be reported in the same manner. Generally, the findings of the quantitative can be made sense through qualitative findings; not always. There could be something that is not clear enough. So, again, it is worth investigating it further.

The fourth is in the order of attributes in OP (Figure 3). They are: academically certifiable $\left(\mathrm{Y}_{11}\right)$, nationally reputable $\left(\mathrm{Y}_{12}\right)$, and globally respectable $\left(\mathrm{Y}_{13}\right)$; the same in order as compared to the initial framework. This is a positive sign. A quantitative approach is to achieve generalisable data and the qualitative approach is to explore and probe into interesting aspects from statistical analysis stance. Ideally, there should be a link between the two with the quantitative being used to inform the direction of the qualitative investigation. Therefore, they do not necessarily have to match, instead one should inform the other. It is fortunate for this regard that what was established under qualitative procedures perfectly approved under a quantitative approach.

The fifth concern is on the rank of attributes within the reliable system $\left(\mathrm{Y}_{4}\right)$; see Figure 3 for the following explanation. They are: ICT set-up $\left(\mathrm{Y}_{41}\right)$, referral scheme $\left(\mathrm{Y}_{43}\right)$, and feedback loop $\left(\mathrm{Y}_{42}\right)$; slightly different in order as compared to the initial framework. The rank of attributes in service excellent $\left(\mathrm{Y}_{2}\right)$ is: academic service $\left(\mathrm{Y}_{21}\right)$, administrative service $\left(\mathrm{Y}_{23}\right)$, and operational service $\left(\mathrm{Y}_{22}\right)$; slightly different in order as compared to the initial framework. The rank of attributes in the quality product $\left(\mathrm{Y}_{3}\right)$ is: graduates $\left(\mathrm{Y}_{31}\right)$, publications $\left(\mathrm{Y}_{32}\right)$, and social responsibility $\left(\mathrm{Y}_{33}\right)$; the same in order as the initial framework.

A comparable challenge as the first three effects also takes place in this dot. Two out of the three attributes have slightly different order as compared to the initial operational framework. The order of attributes of the first two dimensions in this variable is clearly different from the initial configuration. There should be a more comprehensive inquiry searching for adequate arguments for why this is so. Similar to the first query, what would be the potential causes of why this issue comes to pass. Is it a question of a theoretical constriction, methodical limitation, and/or technical constraint?

Having considered those five elaborative consequences, it can be conditionally formulated on two main issues that arise and need further attempts. The first concern is related to the need for reviewing the operational framework as a prolongation of the conceptual framework. It needs to be clarified whether or not the tested operational framework tightly supported by related and relevant previous studies. The second interest is related to the need for reassessing approach used, that is the mixed methods: exploratory design. For this kind of study, for example, it might be more appropriate using explanatory design rather than exploratory design. Explanatory design means that the quantitative approach is completed first and then followed by a qualitative approach afterward (Creswell and Clark, 2011). This does not mean that the result of this study is 
useless or even wrong. This is how to improve the results so that it is more applicable beyond the Universitas Terbuka milieu.

Before validating a comprehensive conclusion under the mixed methods, we need to reflect on the SEM output whether or not it is methodically in the "good-fit" category (Table 3). If so, it is reliable to utilise the analysis and engender loading factors to confirm the power of interrelations on all variables and dimensions (attributes) engaged (Hooper et al., 2008). The analysis constructively confirmed that they were satisfactory.

Table 3 The goodness of fit of the tested operational framework

\begin{tabular}{lccc}
\hline Goodness of fit & Cut-off values & Results & Notes \\
\hline$R M R_{\text {Root Mean Square Residual }}$ & $\leq 0.05$ or $\leq 0.10$ & 0.09 & Good Fit \\
$R M S E A_{\text {Root Mean Square Error of Approximation }}$ & $\leq 0.08$ & 0.07 & Good Fit \\
GFI $_{\text {Goodness of Fit }}$ & $\geq 0.90$ & 0.93 & Good Fit \\
AFFI $_{\text {Adjusted Goodness of Fit Index }}$ & $\geq 0.90$ & 0.91 & Good Fit \\
CFI $_{\text {Comparative Fit Index }}$ & $\geq 0.90$ & 0.91 & Good Fit \\
$N F I_{\text {Normed Fit Index }}$ & $\geq 0.90$ & 0.91 & Good Fit \\
$N N F I_{\text {Non-Normed Fit Index }}$ & $\geq 0.90$ & 0.92 & Good Fit \\
IFI $_{\text {Incremental Fit Index }}$ & $\geq 0.90$ & 0.88 & Marginal Fit \\
RFI $_{\text {Relative Fit Index }}$ & $\geq 0.90$ & 0.91 & Good Fit \\
\hline
\end{tabular}

From Table 3, we can observe that eight cut-off values were included in the good-fit and one in the marginal-fit category. It means the validated operational framework was statistically dependable. Despite there were three main variables hypothetically invalidated by the analysis and some orders of the variables and dimension slightly different from the initial tested framework, methodologically it was still valid and reliable. It means that to a certain extent the results can still be used as a point of reference (Gozali and Fuad, 2008).

Correspondingly, three inferences ought to be further explored viewed from the statistical stance. The first is on the variance obtained under an exploratory design. The second is on the reasons adjacent to the respondents' characteristics. The third is about the implication of findings discovered, especially on the power of relationship amongst variables engaged, for the next related inquiry with a comparable topic.

First. The OP was qualitatively interrelated with selection and recruitment, work definition, training program, performance measurement, compensation scheme, career planning, quality assurance knowledge, and employee participation. OP positively interrelated with service excellence, quality products, and reliable systems (called OO). However, three main factors of independent variables (HRM) were not statistically interrelated with the moderating variable (OP, namely selection and recruitment, work definition, and quality assurance knowledge). This implies that OP was still able to moderate between independent variables (HRM) and dependent variables (OO) despite minor variance exist. In other words, the qualitative and quantitative ends slightly varied but coincidentally they did not substantially contradict one another.

Plausible drives on why and how the three factors (selection and recruitment, work definition, and quality assurance knowledge) excluded by the quantitative procedure, as the independent variables in this inquiry, can be described in this way. In the Universitas Terbuka tradition, the selection and recruitment process is said to be excellent if it was 
transparent, fair, and based on knowledge, skills, and attitudes viewed from stakeholders' views. Looking at experiences in the process of selecting and recruiting staff in the past 20 years, it is always in accordance with the national standard as determined by the Government (Universitas Terbuka is a state University). Therefore, most staff as respondents in this research do not consider some problems problems that might hamper organisational performance because of this quality anymore (Universitas Terbuka, 2018).

Likewise, the definition of work and quality assurance systems in the last 20 years have even been standardised; recognised both internally/externally and nationally/ internationally. The work definitions and quality assurance systems at Universitas Terbuka are both standard and very well understood from junior staff to senior ones. Additionally, every year there is always training and auditing activities on strengthening the quality assurance system to ensure the organisation's performance meets the specified standards in accordance with the stated work definition. To ensure that, the internal and external audit process is continuously carried out regularly. As a result, most respondents considered that these two factors are no longer an issue anymore (Universitas Terbuka, 2018; Universitas Terbuka, 2019).

The exploratory design was conducted by synthesising related theories and end up with a set of hypothesis. A quantitative framework is then established prior to interpretation (Creswell and Clark, 2011). This is to assess the qualitative aspects of exploratory findings. Before building the operational framework, the conceptual framework should be first established as it will be then statistically scrutinised. The results showed that three of the 11 hypotheses were not validated by the analysis. Besides, the order of dimensions/attributes involved in the initial framework was disharmony as compared to the quantitative upshots. It implies that the quantitative method imperfectly approved the qualitative discoveries. Again, even it was so, the results can still be used should the comparable study be conducted not only in the ODL environment but also in other institutions at large.

Second. Most respondents were reasonably experienced in the management area observed from their background, position, working experience, age, and qualification (Table 2). It is then plausible that they are able to foresee that the three invalidated hypotheses as less significant related to OP. But, it is unfortunate that one of the attributes in OP (academically certifiable) falls in Q1. It seems that most faculty found complications in assuring accreditation (academically certifiable) of the study program institutionally.

Based on the previous experiences, the difficulty of Universitas Terbuka to acquire accreditation from the National Board of Accreditation in Study Program level due to the instrument used to do the assessment processes. Universitas Terbuka is the only tertiary institution that operates an ODL system in Indonesia while the instruments used are for face-to-face university (Sembiring, 2019). It was a subjective and predictive reason on why one critical attribute (academically certifiable) falls in Q1. To find out a more rational motive for this issue, however, it needs further inquiry to find the real motives for this discrepancy.

Third. Future research might involve academics or experts from other institutions. There must be a balance between qualitative and quantitative outcomes. It is important to bear in mind that we are in the position of establishing and promoting highly regarded OP in ODL milieu. This is to assure OO can be accomplished under an effective HRM system in ODL setting through the Universitas Terbuka tradition. 
It is conjectured that those divergences might be conceptually related to the origination of the research problem and questions in the first place. No matter how the research questions are generated, scholars using mixed methods research uniformly agree that the questions of interest play a central role in the process of designing any mixed methods study. The importance of the research problem and questions is a key principle of mixed methods research design. This perspective stems from the pragmatic foundations for conducting mixed methods research where the notion of 'what works' applies well to selecting the methods that 'work best' to address problems and questions of an inquiry (Creswell, 2014, p.60). The divergent results of mixed methods, however, should be kept in the same report to give a chance to explore more the phenomenon by arranging further comparable study. Such findings should enrich the discussion and may emphasise the need for future research in this area of interest.

The potential for divergence is easy to understand when studying a reasonably complex human phenomenon, like in this inquiry. To a certain extent, the quantitative methods could well emphasise one aspect of what we are studying while the qualitative methods could emphasise another different aspect. It is not necessarily the case that one is right and the other is wrong. Instead, they may each be capturing different aspects of what we are trying to study further. Therefore, just put the two into the same writing and emphasising the divergence explicitly. The goal is to make different results into an interesting and challenging problem in this piece of work to consider implementing comparable topics in the future.

\section{Conclusions and consequences}

This study is finally able to clarify five principal factors underpinning OP. The study is also able to exhibit how and in what behaviour all factors engaged interdepended one another. The results positively showed that OP is dependable to uphold OO, especially in ensuing reliable systems, excellent service, and quality products. Besides, the University has been in service since 1984 with more than 1.7 million graduates and at the same time is serving 320,000 students per semester. Having considered those factual numbers, it is strongly believed that Universitas Terbuka is on the right path to contribute to the nation through dependable OP in concordance with guaranteeing reliable systems, delivering excellent service, and providing quality products; referred to as the so-called quality graduates and quality publications.

Furthermore, this result ensures that OP is significant to reinforce OO through effective HRM. OP is relevant in assuring $O O$ so that it would be academically certifiable, nationally reputable, and globally respectable. Through the IPA-CSI procedure, 18 out of 27 pertinent attributes were acknowledged as the essential confirmation that OP progress in Universitas Terbuka, with the tagline making higher education open to all, is promising towards being world quality ODL Institution (Universitas Terbuka, 2017; Sembiring, 2020). This will positively be achieved on condition that the 18 attributes in Q2 are constantly retained and the four attributes fall in Q1 should simultaneously be altered to Q2.

This inquiry, however, has encountered considerable discrepancies between what was obtained from a qualitative approach as compared to the quantitative one. Three out of the 11 hypotheses evaluated were not statistically validated by the analysis. Pragmatically, this indicated that the established qualitative framework is imperfectly 
verified by the quantitative analysis. To make it more parallel, further inquiry is unquestionably required. How? That can be accomplished by broadening the scope of the study and encompassing other academic communities from other universities or institutions.

By engaging other related parties, it will give benefits not only for the management, staff, and students of Universitas Terbuka but also for policymakers in public sectors, especially for the government of Indonesia. Besides, it is also valuable for other institutions together with their governments that have comparable situations and contexts with Indonesia in assuring OP through a comprehensive HRM system. It aims at assuring OO to develop human capital for the needs of $21^{\text {st }}$ Century challenges through every university and/or institution; including and mainly through Universitas Terbuka tradition (Sembiring, 2020).

By involving and enlarging the scope of the study, it will practically make the consequences of qualitative and quantitative results might be getting nearer utilising exploratory design as part of mixed methods. This auxiliary inquest is imperative to reduce or even eliminate plausible divergence with a broader scope of discourse. Technically, this endeavour can be attained by combining a more relevant approach, intensifying the theoretical exposures, and/or especially expanding the population and/or sample size properly (Bujang and Adnan, 2016). These clarifications can be regarded as one way of performing a more appropriate comparable study in OP based on HRM in accordance with ensuing excellent service, quality products, and reliable systems in the ODL environment. By considering these reviews, the result of this study is expected to be utilised not only by the Universitas Terbuka internally but also by other universities or institutions that have comparable interests.

\section{References}

Akhtar, S., Arif, A., Rubi, E. and Naveed, S. (2011) 'Impact of organizational learning on organizational performance: study of higher education institutes', International Journal of Academic Research, Vol. 3, No. 5, pp.327-331. Available online at: https://www.researchgate.net/publication/257924811_IMPACT_OF_ORGANIZATIONAL_ LEARNING_ON_ORGANIZATIONAL_PERFORMANCE_STTUDY_OF_HIGHER_ EDUCATION_INSTITUTES (accessed on 2 August 2019).

Becker, B.E. and Gerhart B. (1996) 'The impact of human resource management on organizational performance', The Academy of Management Journal, Vol. 39, No. 4, pp.779-801. DOI: 10.2307/256712 (accessed on 1 July 2019).

Bujang, M.A. and Adnan, T.H. (2016) 'Requirements for minimum sample size for sensitivity and specificity analysis', Journal of Clinical and Diagnostic Research, Vol. 10, No. 10, pp.YE01YE06. ISSN-0973-709X. DOI: 10.7860/JCDR/2016/18129.8744. Available online at: https://www.ncbi.nlm.nih.gov/pmc/articles/PMC5121784/ (accessed on 27 March 2020).

Cochran, W.G. (1977) Sampling Techniques, $3^{\text {rd }}$ ed., John Wiley \& Sons, New York.

Creswell, J.W. and Clark, V.L.P. (2011) Designing and Conducting Mixed Methods Research, $2^{\text {nd }}$ ed., Sage Publication, Los Angeles.

Creswell, J.W. (2014) Research Design: Qualitative, Quantitative, and Mixed Methods Approaches, $4^{\text {th }}$ ed., Sage, Los Angeles.

Deng, J. and Pierskalla, C.D. (2018) 'Linking importance-performance analysis, satisfaction, and loyalty: A study of Savannah, GA', Sustainability, Vol. 10, No. 704, pp.1-17. Available online at: www.mdpi.com/journal/sustainability. DOI:10.3390/su10030704 (accessed on 27 April 2019). 
Fowler, F.J. Jr. (2014) Survey Research Methods, $5^{\text {th }}$ ed., Sage Publication, Los Angeles.

Ghozali, I. and Fuad (2008) Structural Equation Modeling (SEM): Teori dan Konsep dengan Program LISREL 8.80. Badan Penerbit Universitas Diponegoro, Semarang, Indonesia.

Haddad, M.E.O., Ferreira, N.S.C. and Faria, A.A. (2014) 'The use of educational technologies in distance education-Enabling the appropriation of teaching and learning process', Open Journal of Social Sciences, Vol. 2, No. 1, pp.54-58. Available online at: http://dx.doi.org/10.4236/jss.2014.21006 (accessed on 24 March 2020).

Hair, J.F.Jr., Black, W.C. Babin, B.J. and Anderson, R.E. (2009) Multivariate Data Analysis with Readings, $7^{\text {th }}$ ed., Prentice Hall, Inc, New Jersey.

Harsasi, M. (2018) 'Organizational performance in Universitas Terbuka'. Paper presented at the 32 Asian Association of Open Universities Annual Conference, hosted by Hanoi Open University, 24-26 October 2018, Hanoi, Vietnam. Available online at: https://aaou2018.hou.edu.vn/conference-proceeding-vol-1-ebook/ (accessed on 1 August 2019).

Hooper, D., Coughlan, J., and Mullen, M.R. (2008) 'Structural Equation Modelling: Guidelines for Determining Model Fit, The Electronic Journal of Business Research Methods, Vol. 6, No. 1, pp.53-60. Available online at: http://mural.maynoothuniversity.ie/6596/ (accessed on 27 March 2020).

Imran, R., Majeed, M. and Ayub, A. (2012) 'Enhancing performance: examining the role played by the high-performance work system', International Journal of Economics and Financial Issues, Vol. 5 (Special Issue), pp.379-384. ISSN: 2146-4138. Available online at: http://www.econjournals.com (accessed on 2 August 2019).

Kanyemba, M., Iwu, C.G. and Allen-Ile, C. (2015) 'Impact of recruitment and selection on organizational productivity. Evidence from staff of a university in South Africa', Corporate Ownership and Control, Vol. 12, No. 2), pp.177-185. DOI: 10.22495/cocv12i2c1p1 (accessed on 1 August 2019).

Marks, R.B,. Sibley, S.D. and Arbaugh, J.B. (2005) 'A structural equation model of predictor for effective online learning', Journal of Management Education, Vol. 29, No. 4, pp.531-563.

Patro, C.S. (2013) 'The impact of employee engagement on organization's productivity'. Proceedings of the $2^{\text {nd }}$ International Conference on Managing Human Resources at the Workplace, December 13-14, 2013. ISBN: 978-81-922146-5-8. Available online at: https://www.researchgate.net/publication/281967834_The_Impact_of_Employee_

Engagement_on_Organization's_Productivity (accessed on 2 August 2019).

Sayfried, M. and Pohlenz, P. (2018) 'Assessing quality assurance in higher education: quality managers' perceptions of effectiveness', European Journal of Higher Education, Vol. 8, No. 3, pp.258-271. http://doi.org/10.1080/21568235.2018.1474777.

Schuler, R.S. and Jackson, S.E. (2014) 'Human resource management and organizational effectiveness: yesterday and today', Journal of Organizational Effectiveness: People and Performance, Vol. 1, No. 1, pp.35-55. DOI: 10.1108/JOEPP-01-2014-0003. Available online at: https://www.researchgate.net/publication/270798201_Human_resource_management_and_ organizational_effectiveness_Yesterday_and_today (accessed on 7 August 2019).

Sembiring, M.G. (2015) 'Validating student satisfaction related to persistence, academic performance, retention, and career advancement within ODL perspectives', Open Praxis, Vol. 7, No. 4, pp.325-337 (ICDE Prizes for Innovation and Best Practice, $2^{\text {nd }}$ ed.). DOI: http://dx.doi.org/10.5944/openpraxis.7.4.249

Sembiring, M.G. (2017) 'Exploratory study of academic excellence associated with persistence in ODL setting', Asian Association of Open Universities Journal, Vol. 12, No. 2, pp.125-136, https://doi.org/10.1108/AAOUJ-01-2017-001513

Sembiring, M.G. (2018a) 'Modeling the determinants of effective online tutoring programs', Turkish Online Journal of Distance Education, Vol. 19, No. 3, pp.128-139. DOI: 10.17718/tojde.445114. Available online at: http://tojde.anadolu.edu.tr/volume-19-issue-3year-2018.html (accessed on 27 April 2019). 
Sembiring, M.G. (2018b) 'Validating student satisfaction with a blended learning scheme in Universitas Terbuka setting', International Journal for Mobile Learning and Organisation, Vol. 12, No. 4, pp.394-412. DOI: 10.1504/IJMLO.2018.095166. Available online at: http://www.inderscience.com/offer.php?id=95166 (accessed on 27 April 2019).

Sembiring, M.G. (2018c) 'Technological, institutional and situational influences on student persistence', International Journal of Services and Standards, Vol. 12, No. 3/4, pp.261-274. DOI: 10.1504/IJSS.2018.100216. Available online at: https://www.inderscience.com/info/ inarticle.php?artid=100216 (accessed on 26 March 2020).

Sembiring, M.G. and Rahayu, G. (2019) 'Validating the moderating role of satisfaction between service quality and accomplishment in ODL perspectives'. Proceedings International Conference on Open and Innovative Education, pp.356-368. Open University of Hong Kong, Hong Kong. Available online at: http://icoie2019.ouhk.edu.hk/ (accessed on 2 August 2019).

Sembiring, M.G. (2020) 'An Improvement of Open Distance Higher Education Ecosystem: Developing Indonesia's Golden Generation', Professorship Inauguration Manuscript to be presented at the Open Senate Session of Universitas Terbuka, Universitas Terbuka, Tangerang Selatan, Indonesia (In Press).

Shahzavar, Z. and Tan, B.H. (2011) 'Developing a questionnaire to measure students' attitude toward the course blog', Turkish Online Journal of Distance Education, Vol. 13, No. 1, pp.200-210.

Shefali, P. and Srivastava, R.K. (2017) 'Factors influencing organizational effectiveness in the educational sector', European Journal of Education Studies, Vol. 3, No. 3, pp.271-295. Available online at: www.oapub.org/edu - DOI: 10.5281/zenodo.292944 (accessed on 2 August 2019).

Torabia, F. and El-Denb, J. (2017) 'The impact of knowledge management on organizational productivity: A case study on Koosar Bank of Iran', Procedia Computer Science, Vol. 124 (2017), pp.300-310. https://doi.org/10.1016/j.procs.2017.12.159 (accessed on 1 August 2019).

Universitas Terbuka (2017) Rencana Strategi Bisnis Universitas Terbuka 2017-2020, Universitas Terbuka, Tangerang Selatan, Indonesia.

Universitas Terbuka (2018) Universitas Terbuka 2017 Yearly Report, Universitas Terbuka, Tangerang Selatan, Indonesia.

Universitas Terbuka (2019) Universitas Terbuka 2018 Yearly Report, Universitas Terbuka, Tangerang Selatan, Indonesia.

Wong, M.S., Hideki, N. and George, P. (2011) 'The use of IPA in evaluating Japan's e-government services', Journal of Theoretical and Applied Electronic Commerce Research, Vol. 6, No. 2, pp.17-30. Available online at: www.jtaer.co (accessed on 9 July 2015). 


\section{Appendix A: The Questionnaire of the Study}

The Role of Organisational Performance in Moderating Human Resource Management and Outstanding Outcomes in ODL Context [Universitas Terbuka | Survey | May-June 2019]

Please provide a piece of information and your responses to the statements enclosed in the following two tables. To start with, please first complete your personal information.

\begin{tabular}{|c|c|c|c|c|c|}
\hline$\overline{\text { Faculty }}$ & [] Education & [] Social & [] Economics & [] Sciences & \\
\hline Echelon & [] One & [ ] Two & [ ] Three & [ ] Four & $\begin{array}{l}\text { Non- } \\
\text { Echelon }\end{array}$ \\
\hline $\begin{array}{l}\text { Work Experience } \\
\text { year }\end{array}$ & [ ] $1-5$ & [ ] 6-10 & [ ] $11-15$ & [ ] 16-20 & {[]$\geq 21$} \\
\hline Age year & {[]$\leq 30$} & [ ] $31-40$ & [ ] $41-50$ & [ ] $51-60$ & {[]$\geq 61$} \\
\hline $\begin{array}{l}\text { Academic } \\
\text { Position }\end{array}$ & [ ] Professor & [] Senior L & [] Lecturer & [] Assistant & $\begin{array}{l}\text { Candi } \\
\text { date }\end{array}$ \\
\hline Ed. Background & [ ] S3 & [] $\mathrm{S} 2$ & Office & [ ] Central & $\begin{array}{l}{[]} \\
\text { Regional }\end{array}$ \\
\hline
\end{tabular}

Next, please respond to each statement in the following table accordingly.

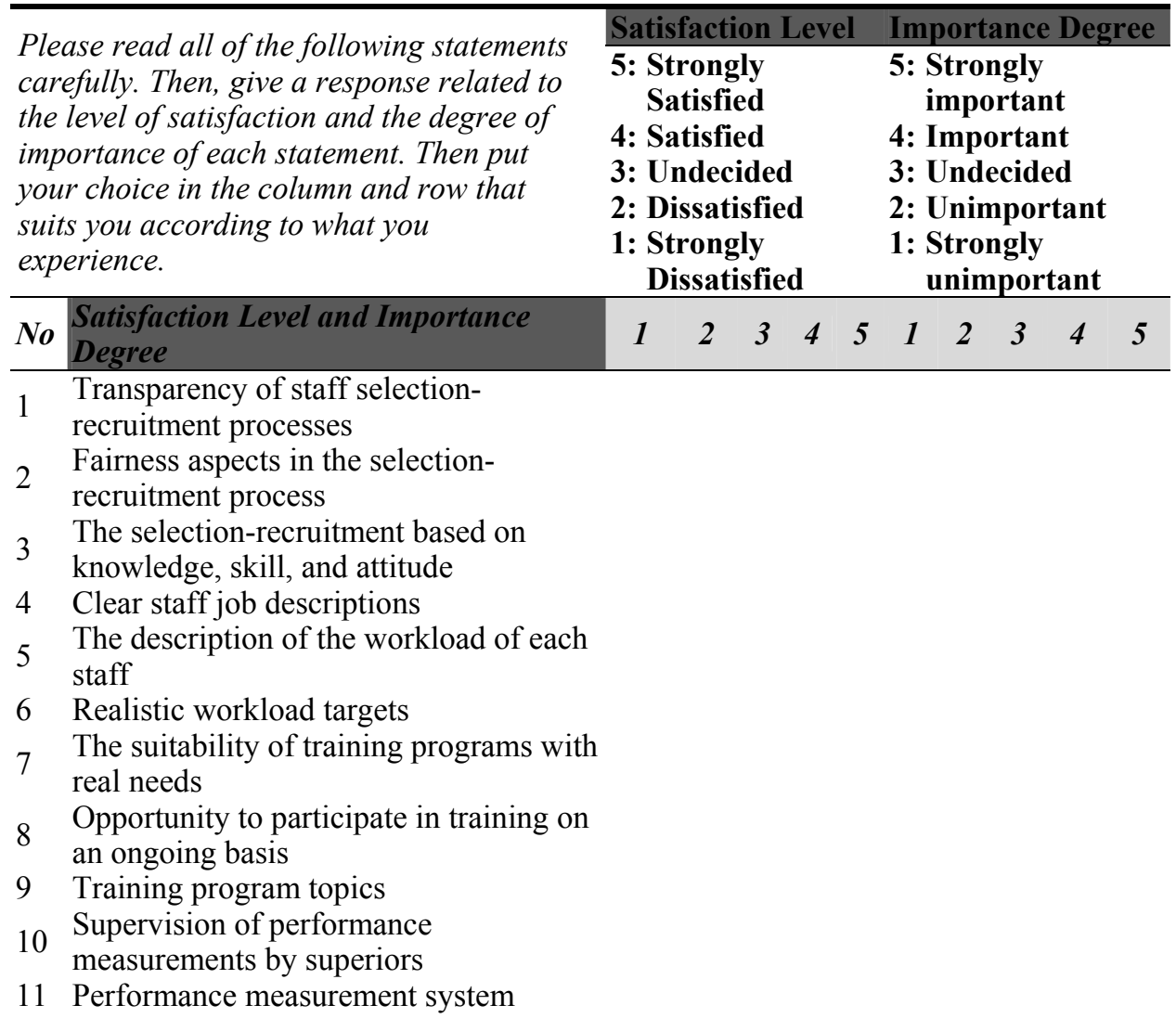


12 Output-based performance evaluation

12 measures

13 Compensation scheme (income)

14 Amount of compensation

15 Other compensation systems exist

16 The openness of the staff career path

17 The ultimate achievement of an

academic career

18 Achievement of career peaks in the academic and structural fields

19 The existence of a quality assurance system

20 Quality assurance of academic services for staff careers

21 The result of an academic career quality assurance system

22 Staff involvement in developing the vision of the institution

23 Staff contributions in the decisionmaking process

24 Staff participation in determining unit leaders

Achievement of study program accreditation

Achievement of University accreditation process

Obtaining international certification / accreditation

28 Study program accreditation determines the quality of academic services

Institutional accreditation influences the quality of operational services

30 International certification guarantees the managerial quality of the institution

31 Organisational performance is directly 1 proportional to the quality of graduates

32 Academic organisational performance

32 determines the quality of publications

33 International recognition strengthens

33 social service coverage capacity

34 International certification is a sign of the reliability of the ICT system

35 Institutional accreditation supports the feedback service system to be reliable

36 Utilisation of non-own resources is a result of passing the accreditation Obtaining accreditation/certification guarantees the quality of all services with a high level of satisfaction felt by

$\begin{array}{lllll}1 & 2 & 3 & 4 & 5\end{array}$

$\begin{array}{lllll}1 & 2 & 3 & 4 & 5\end{array}$

$\begin{array}{lllll}1 & 2 & 3 & 4 & 5\end{array}$

$\begin{array}{lllll}1 & 2 & 3 & 4 & 5\end{array}$

Please choose one

$\begin{array}{lllll}1 & 2 & 3 & 4 & 5 \\ \text { response, where: }\end{array}$

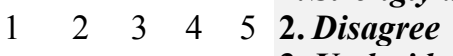

3. Undecided

$\begin{array}{llllll}1 & 2 & 3 & 4 & 5 & 4 . \text { Agree }\end{array}$

$\begin{array}{lllll}1 & 2 & 3 & 4 & 5\end{array}$

5. Strongly agree all parties (staff, students, and partners)

Thank you (May-June 2019) 